\title{
IMPACT OF ENVIRONMENTAL TOBACCO SMOKE EXPOSURE ON ADULTS WITH ASTHMA EXACERBATION
}

\author{
SUTARYONO ${ }^{1,2 *}$, HARTONO $^{3}$, ARI PROBANDARI ${ }^{4}$, PRABANG SETYONO \\ ${ }^{1}$ Doctoral Program in Environmental Science, Universitas Sebelas Maret, Indonesia. ${ }^{2}$ Department of Pharmacy, School of Health Science \\ Muhammadiyah Klaten, Indonesia. ${ }^{3}$ Department of Physiology, Faculty of Medicine, Universitas Sebelas Maret, Indonesia. ${ }^{4}$ Department \\ of Public Health, Faculty of Medicine, Universitas Sebelas Maret, Indonesia. ${ }^{5}$ Department of Biology, Faculty of Mathematics and Natural \\ Sciences, Universitas Sebelas Maret, Indonesia. *Email: sutar.on@gmail.com
}

Received: 14 July 2018, Revised and Accepted: 13 December 2018

\section{ABSTRACT}

Objective: Environment tobacco smoke (ETS) exposure in the household is dangerous to infants and children. Nicotine residue inhaled in the respiratory tract metabolized into cotinine which has the possibility of causing inflammation which can result in asthma exacerbation. The impact created by the exposure of ETS on children suffering from asthma is the sole objective of this research work.

Methods: A cohort study was carried out among 114 asthma patients aged 12-18 years old at three hospitals from January 2016 to March 2017. Data were obtained using self-reported questionnaires and cotinine urine test. The data analysis was carried with the use of Cox proportional hazard model with $95 \%$ confidence interval (CI).

Results: The result of the research showed that $57 \%$ of the patients got the trigger (event). The respondents consisted of $61.5 \%$ of female, average age of 15 years, $50.8 \%$ of upper secondary education, $55.4 \%$ of body mass index (BMI) normal, and $63.1 \%$ low economic status persons. Median survival for the ETS-exposed group was in a $9^{\text {th }}$ week, while the median survival for the ETS non-exposed group was $>12$ weeks. Multivariate exposure of ETS with asthma exacerbation was hazard ratio (HR), 2.17; 95\% CI, 1.23-3.83, $\mathrm{p}=0.008$ and gender $\mathrm{HR}, 1.72 ; 95 \% \mathrm{CI}, 1.04-2.85, \mathrm{p}=0.035$.

Conclusion: ETS exposure in the household increases the risk of asthma exacerbation. Controlling the environment and education of children to avoid ETS exposure should be intensified.

Keywords: Environmental tobacco smoke, Cotinine, Survival, Asthma, Exacerbation.

(c) 2019 The Authors. Published by Innovare Academic Sciences Pvt Ltd. This is an open access article under the CC BY license (http://creativecommons. org/licenses/by/4. 0/) DOI: http://dx.doi.org/10.22159/ajpcr.2019.v12i3.28498

\section{INTRODUCTION}

Epidemiological studies show that smoking is a global health problem and it is seen as a risk factor for the emergence of various medical disorders, especially some non-communicable diseases [1]. Environment tobacco smoke (ETS) has to do with the pollution of the environment, most rooms, with tobacco smokes, and that is why it is usually referred to as second-hand smoke. It comes with devastating impacts such as cardiovascular death and respiratory diseases, infections, behavioral problems, low birth weight, sudden infant death syndrome, and cancer [2,3]. Groups that are particularly vulnerable to this secondhand smoke are children, so they are easily affected by asthma, pneumonia, sinusitis, and different allergies.

Globally, about $40 \%$ of children with respiratory problems got them from smoking parents, as a result of this, about $28 \%$ of children deaths were associated with ETS in 2004 [2]. People that smokes are at risk of developing diabetes mellitus as well as be at increased risk of cancer of the bladder $[4,5]$. Exposure to tobacco smoke can cause heart attacks, strokes, and even sudden death. It was found that smoking causes about $85 \%$ of lung cancers in the United States [6]. Sympathetic overactivity may lead to cardiovascular disease development in smokers. Cigarette smoking also has an adverse effect on serum ferritin, and other hematologic parameters and serum ferritin have been discovered to be one of the most reliable indicators of iron status $[7,8]$. The cyclooxygenase (Cox) proportional hazard model shows a higher hazard ratio (HR) for smokers prognostic impact in patients with lung adenocarcinoma [9].

One of the major effects of ETS that can result in death is asthma. Asthma is a chronic inflammatory disease of the respiratory tract characterized by wheezing, coughing, and chest tightness due to respiratory tract blockages. Epidemiological study of asthma reveals that the prevalence of several countries ranged from $1 \%$ to $18 \%$ [10], while, nationally, in Indonesia, it showed 4.5\% [11]. Asthma is caused by many factors which include gene, family history of allergy and asthma, viral respiratory infections, bacterial colonization, allergic sensitization, body weight, hypertension, and tobacco exposure. These are the main risk factors associated with childhood-onset asthma $[12,13]$

Leftover cigarette smoke on surfaces does not evaporate into the air; however, there is nicotine residue attached to the dust or stuff around us, such as clothes, carpets, walls, furniture, or chairs. Nicotine dust is not going to disappear in a short time, so it will be inhaled by others even though the smoker has left the place $[14,15]$.

More than 5200 chemical components are found in cigarette smoke in the form of particles and steam [16]. These chemicals are dangerous and can cause damages to the respiratory tract, in such a way that they can block overall breathing work [17]. One of these chemicals is nicotine, and it has a secondary immunomodulatory effect of eosinophil function, by inhibiting the release of pro-inflammatory cytokines from macrophages $[18,19]$.

ETS exposure in the household can increase the severity of asthma in children because while they are on the floor, they inhale dust of carpet, mildew, mite, and others which are equivalent to sucking four cigarettes a day. Over $90 \%$ of children spend their time indoors, and because of the ETS, indoor air pollution gives more harmful health effects than outdoor air pollution [20]. 
ETS exposure in the household can be inhaled through breath into the alveoli and then spread into the blood circulation if not stopped. In the metabolism, there are CYP2A6 genes, which are genes encoding P450 2a6 of cytochrome enzyme. This enzyme is responsible for $70 \%-90 \%$ of nicotine metabolism in blood to cotinine [21-24]. Therefore, ETS exposure can be assessed through cotinine measurement in urine, serum, or saliva.

Nicotine in cigarette smoke can trigger inflammation because it has a direct effect on neutrophils and macrophages through the activation of nicotinic acetylcholine receptors in nerve cells as well as non-nerve cells such as monocytes and endothelial [25]. Several studies have also shown an increase in neutrophil inflammation in the bronchi and an increased number of neutrophils will trigger an increase in eosinophils, which will secrete inflammatory mediators that play a significant role in triggering asthma. Decreased IgE serum, blood eosinophils, and fractional exhaled nitric oxide non-smoker's and former smoker's ages had higher thymic stromal lymphopoietin than those that never smoke. In addition, goblet cell numbers will increase and hypersecretion of mucus in the respiratory tract [26]. The presence of cotinine urine levels in smokers has a positive relationship to increased levels of PGE-M and LTE4. This plays a role in inflammation and carcinogenesis [27].

The novelty of this study is to assess the risk impact associated with exposing children living with asthma to ETS in the family. We hypothesize that asthmatic children who are exposed to ETS in the family will experience an asthma exacerbation faster than those who are not exposed to ETS in the family.

\section{METHODS}

\section{Study design}

A cohort study was carried out among 114 asthma patients from three hospitals - Center for Healthy Lung Community (BBKPM), Surakarta, Dr. Moewardi Hospital, Surakarta, and Lung Health Center (Balkesmas) Klaten, Central Java, Indonesia from January 2016 to March 2017 with the inclusion of some criteria. The research was carried out on respondents between the ages of 12 and 18 years. Survival analysis was carried out for asthma exacerbation.

\section{Research ethics}

We conducted a written informed consent before the data collection. The research ethics were obtained from the Ethics Committee of the Faculty of Medicine, Universitas Sebelas Maret, Indonesia.

\section{Data collection}

The data of respondents related to demography, BMI, and history of environmental tobacco exposure in the household were based on selfreport gotten through interview and questionnaire at the beginning of the research. The history of cigarette use includes the presence of smokers at home and number of cigarettes per day ( 1 to 10,11 to 19,20 to 29 , and $>30$ /day). Data were evaluated at 12 weeks or 3 months through self-report or medical records from the hospital to obtain sensory time analysis data. Urine sampling was also done in early research on every subject. Urine samples were used to determine levels of cotinine with the use of EnzymeLinked Immunosorbent Assay method [28-31]. Urine cotinine analysis data were classified into two categories which are: $<15 \mathrm{ng} / \mathrm{mlal}$ so known as nonexposed and higher than $15 \mathrm{ng} / \mathrm{ml}$ also known as exposed [28].

\section{Data analysis}

Data on demography, BMI, cigarette use, and cotinine concentration were obtained with the use of frequency distribution and percentage. We used the Log-rank test to evaluate the difference in time-to-event endpoints between patient groups. Multivariate Cox Proportional Hazard Models were fitted using all the covariates, yielding HRs 95\% confidence interval (CI) with SPSS software.

\section{RESULTS}

Based on medical records from three hospitals; Center for Healthy Lung Community (BBKPM), Surakarta, Dr. Moewardi Hospital, Surakarta, and
Lung Health Center (Balkesmas) Klaten, Central Java, Indonesia from January 2016 to March 2017. The total number of asthma patients in the three health-care facilities was 4872 with the number of children with asthma recorded to be 726 . There were 114 children who fulfilled the criteria, and they were used as samples. During the research period, it was found that the trigger status (event) was $57 \%$ and the sensor was $43 \%$. Survival time showed that $50 \%$ respondent suffered the trigger in the $10^{\text {th }}$ week, while the ETS-exposed group was in the $9^{\text {th }}$ week.

Baseline characteristics as a single predictor of asthma exacerbation are summarized in Table 1. Cohort survival time showed that most of the respondents who suffered events were $61.5 \%$ female, at the mean age of 15 years, $50.8 \%$ of upper secondary education, $55.4 \%$ of BMI normal, and income $<\$ 105(63.1 \%)$. Cotinine test as ETS biomarker showed that a high concentration of cotinine suffered more events (75.4\%).

Table 1: The baseline of sociodemographic characteristics, ETS exposure, and trigger in adults with asthma exacerbation

\begin{tabular}{|c|c|c|c|}
\hline \multirow[t]{2}{*}{ Variables } & \multirow{2}{*}{$\begin{array}{l}\text { Event } \\
\text { n (\%) }\end{array}$} & \multirow{2}{*}{$\begin{array}{l}\text { Sensor } \\
\mathrm{n}(\%)\end{array}$} & \multirow[t]{2}{*}{ p value $*$} \\
\hline & & & \\
\hline \multicolumn{4}{|l|}{ Age } \\
\hline $12-15$ & $30(46.15)$ & $32(65.31)$ & \multirow[t]{3}{*}{0.067} \\
\hline 16-18 & $35(53.85)$ & 17 (34.69) & \\
\hline Mean \pm SD & $15 \pm 2.5$ & & \\
\hline \multicolumn{4}{|l|}{ Gender } \\
\hline Female & $40(61.54)$ & $20(40.82)$ & \multirow[t]{2}{*}{0.065} \\
\hline Male & $25(38.46)$ & $29(59.18)$ & \\
\hline \multicolumn{4}{|l|}{ Education } \\
\hline Primary & $32(49.23)$ & $33(67.35)$ & \multirow[t]{2}{*}{0.056} \\
\hline Upper secondary & $33(50.77)$ & $16(32.65)$ & \\
\hline \multicolumn{4}{|l|}{ BMI } \\
\hline Normal & $36(55.38)$ & $20(40.82)$ & \multirow[t]{2}{*}{0.186} \\
\hline Abnormal & $29(44.62)$ & 29 (59.18) & \\
\hline \multicolumn{4}{|l|}{ Income } \\
\hline$<\$ 105$ & $41(63.08)$ & $24(48.98)$ & \multirow[t]{2}{*}{0.124} \\
\hline$>\$ 105$ & $24(36.92)$ & $25(51.02)$ & \\
\hline \multicolumn{4}{|l|}{ Cotinine } \\
\hline$>15 \mathrm{ng} / \mathrm{ml}$ & 49 (75.38) & $26(53.06)$ & \multirow[t]{2}{*}{0.010} \\
\hline$<15 \mathrm{ng} / \mathrm{ml}$ & $16(24.62)$ & $23(46.94)$ & \\
\hline
\end{tabular}

*The log-rank test (Mantel Cox) was used for all other characteristics. BMI: Body mass index, ETS: Environment tobacco smoke, Cox: Cyclooxygenase

The result of multivariate analysis with Cox regression (Cox proportional hazard model) showed that some variables, cotinine concentration and demographic variable (gender) have significant correlation with asthma exacerbation (HR, 2.17; 95\% CI, 1.23-3.83) and (HR, 1.72; 95\% CI, 1.04-2.85) (Table 2).

Table 2: Results of the multivariate analysis for overall survival

\begin{tabular}{llcc}
\hline Variable & Level & HR (95\% CI) & p value* $^{*}$ \\
\hline Gender & $($ Female vs. Male $)$ & $1.721(1.040-2.849)$ & 0.035 \\
Cotinine & $(>15 \mathrm{ng} / \mathrm{ml}$ & $2.168(1.226-3.832)$ & 0.008 \\
& and $<15 \mathrm{ng} / \mathrm{ml})$ & & \\
\hline
\end{tabular}

*The Cox regression (Cox Proportional Hazard Model). HR: Hazard ratio, CI: Confidence interval, Cox: Cyclooxygenase

\section{DISCUSSION}

Median survival for both ETS-exposed and non-exposed groups was 10 weeks. It shows that patients with asthma exacerbation will suffer the trigger in the $10^{\text {th }}$ week. Asthma patients with ETS-exposed will rapidly suffer the trigger in the $9^{\text {th }}$ week, while patients with ETS nonexposed were $>12$ weeks. The result has the similarity as the other research that finds an average rate of asthma trigger to be 14 weeks or 3.5 months/year (Figs. 1 and 2) [32].

Hazard survival ETS with urinary cotinine concentration of biomarker and frequency on the trigger of asthma exacerbation was HR, 2.17; 


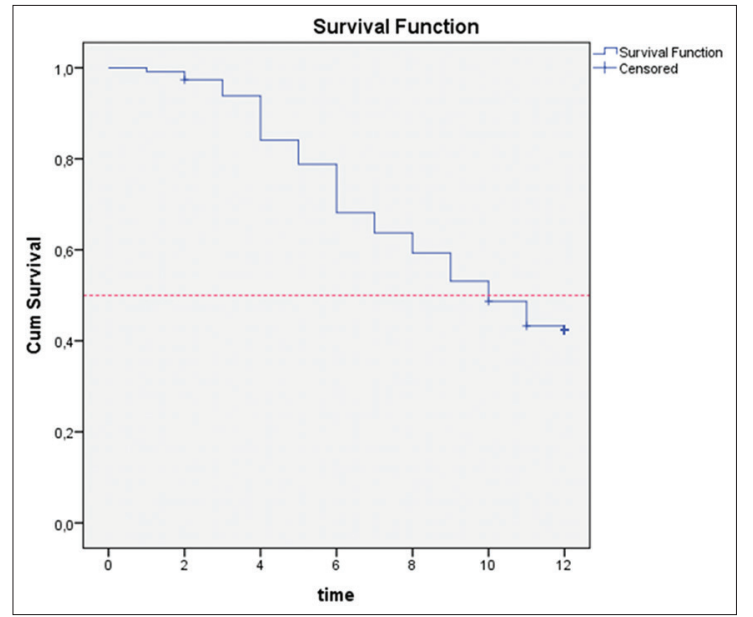

Fig. 1: Survival curve for the asthma exacerbation for all groups

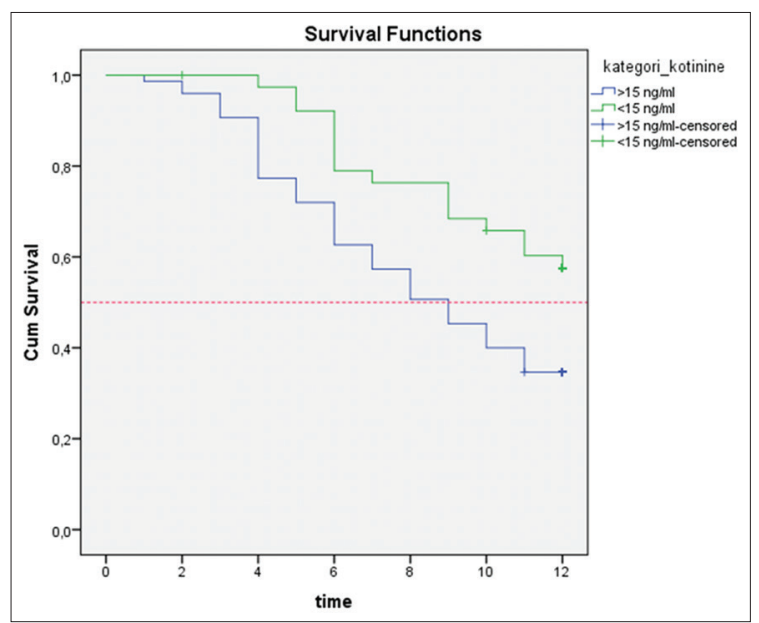

Fig. 2: Survival curve for the asthma exacerbation and cotinine environment tobacco smoke exposure

95\% CI, 1.226-3.832, $\mathrm{p}=0.008$. The result of this research shows that ETS exposure measured with urine cotinine level in children suffering asthma has risk 2 of having asthma exacerbation more rapidly when compared to children with non-exposure of cigarette smoke. There is a research that has proved that mothers who smoke increase fourfold response to histamine as well as high level of cotinine increase the risk of acute asthma exacerbation by 1.8-fold [33]. Children with ETS-exposed have the higher risk of having uncontrolled asthma with $\mathrm{OR}=3.20 ; 95 \% \mathrm{CI}=1.40-6.90$ [34]

Children who live in homes with smoking members have increased cotinine level when compared with those living in homes with no smokers. It shows that ETS exposure is associated with the increasing urinary cotinine and acute exacerbation asthma trigger as well as decreasing lung function of forced expiratory volume in $1 \mathrm{~s}$ and the ratio of forced vital capacity [35]. Around $87.9 \%$ of nontobacco consumers in the United States had detectable acquired serum cotinine levels. Nearly $40 \%$ of children aged 2 months to 2 years are living with at least one smoker, and perhaps, their condition is exacerbated by ETS exposure [36].

A series of epidemiological surveys provide strong evidence of the relationship between parental smoking and the prevalence of asthma in school-age children $[37,38]$. A recent study and meta-analysis of 76 studies have assessed that the effects of pre- or post-natal second-hand smoke exposure are associated with a 21-85\% increased risk of asthma incident [39]. The strongest effect of prenatal maternal smoking on asthma in children aged 2 years old has CI 95\% OR $=1.85$ (1.3-2.5). In adolescence and adults, exposure to passive smoke is also associated with the prevalence of asthma [25].

The increase of urinary cotinine concentration is affected by the number of smokers in a household, and the number of cigarettes smoked. The result showed that the existing home smokers have cotinine concentrations $>15 \mathrm{ng} / \mathrm{ml}$ at most. Category of heavy smokers or higher number of cigarettes $>20$ cigarettes per day areas is shown in Tables 3 and 4.

Table 3: ETS status at home and cotinine concentration

\begin{tabular}{lcc}
\hline ETS Household & \multicolumn{1}{l}{ Cotinine } \\
\cline { 2 - 3 } & $\mathbf{2 1 5} \mathbf{~ n g} / \mathbf{m l}$ & $<\mathbf{1 5} \mathbf{~ n g} \mathbf{m l}$ \\
\hline Home with smoker & $50(66.7)$ & $7(17.9)$ \\
Home without smoker & $25(33.3)$ & $32(82.1)$ \\
\hline ETS. Environment tobacco smoke &
\end{tabular}

Table 4: Number of cigarettes and cotinine concentration

\begin{tabular}{lll}
\hline Number of cigarette & \multicolumn{2}{l}{ Cotinine } \\
\cline { 2 - 3 } & $\mathbf{2 1 5} \mathbf{~ n g} / \mathbf{m l}$ & $<\mathbf{1 5} \mathbf{~ n g} \mathbf{m l}$ \\
\hline$<4$ & $6(12)$ & $3(42.9)$ \\
$5-9$ & $11(22)$ & $1(14.3)$ \\
$10-19$ & $16(32)$ & $1(14.3)$ \\
$20-29$ & $17(34)$ & $2(28.6)$ \\
\hline
\end{tabular}

The variability of each individual against the pattern of cotinine metabolism due to exposure to existing nicotine is quite different. Therefore, it is possible that there may be the existence of cotinine in a household where there is no smoke. This may be attributed to exposure of the inhabitant(s) to cigarette smoke outside the home and other metabolism factors such as genetic variation, race, sex, use of oral contraceptives or other estrogen-containing hormones, renal, and drug failure, including anticonvulsants and rifampin as well as from foods they ate $[23,40]$.

The main physiological features of asthma exacerbation are airways constriction and airflow obstruction, which are reversible. It is produced as a result of the contraction of bronchial smooth muscle, edema, and hypersecretion of mucus. Various trigger factors can lead to exacerbations. Acute bronchoconstriction caused by allergens occurs as a result of the release of mediators from mast cells [41]. The nature of tobacco smoke as inhalants, which are inhaled and exposed directly to the airway, causes a risk factor that has a relationship with asthma exacerbation events in children $[17,42]$.

Our study found that children who lived with smokers tend to have high levels of cotinine and were more likely to experience asthma attacks compared to children who lived in smoke-free homes. These results prove that cigarette smoke triggers inflammation in the respiratory tract which causes asthma attacks exacerbation. Several studies have shown that an increase in the neutrophils inherent the airways will lead to an increase in eosinophils, which will release inflammatory mediators that play a role when asthma attacks [26]. People exposed to cigarettes will find an increase in T lymphocytes, especially CD8+ and macrophages along the airway wall, increased neutrophils in airway secretions, and peripheral airway infiltration with mononuclear cells and macrophages [43].

We also found the female gender more prone to having an asthma exacerbation HR attack, 1.72; 95\% CI, 1.04-2.85). During our study of 114 children, the respondents were mostly girls (61.5\%) and men (38.5\%). Prakruthi et al. conducted a study which proved that women were more prone to asthma than men, out of 90 children examined, $66.7 \%$ females had asthma while $33.3 \%$ men were affected [44]. 
Tobacco smoke exposure may happen in a home (including childhood exposure from parents, siblings, other family members or from the environment). The best recommendation for individuals who have children with asthma exacerbations is the drug reliever and controller; however, long-term use of this medication has side effects. Tamarindus indica L. plants have been studied, and this plant can improve respiratory and anti-asthmatic patterns [45]. Proper preventive efforts and educational controls should be employed to stop smoking. The efforts of public health agencies through their regulations aimed at banning smoking in homes have successfully reduced ETS exposure.

\section{CONCLUSION}

This research revealed that ETS exposure in the household increases the risk of asthma exacerbation. Since children with asthma should have good survival and quality of life, it is, therefore, necessary and expedient to control the environment and educates children to avoid ETS Exposure.

\section{ACKNOWLEDGMENTS}

We would like to thank Directors of the Center for Healthy Lung Community Surakarta, Dr. Moewardi Hospital Surakarta, and the Lung Health Center Klaten, Indonesia, for granting us access to facilities for this study. We also thank all enumerators and laboratory staff for assisting in the process of collecting data

\section{AUTHORS' CONTRIBUTIONS}

All authors in this manuscript have contributed to the research. Sutaryono and Ari Probandari designed the research model, analyzed the data and compiled the manuscript. Sutaryono assisted by Prabang Setyono designed the framework, planned sample preparation and carry out data collection in the field. Hartono contributed in writing the script and supervision of all activities. All authors discussed and provided critical feedback on this text.

\section{CONFLICTS OF INTEREST}

The authors declare that there are no conflicts of interest regarding the publication of this paper.

\section{REFERENCES}

1. World Health Organization. Global Status Report on Noncommunicable Diseases; 2010. Available from: http://www.who.int/about/licensing/ copyright form/en/index.html. [Last accessed on 2016 Aug 29].

2. World Health Organization. Facts on Secondhand Smoke; 2017. Available from: http://www.who.int/news-room/fact-sheets/detail/ tobacco. [Last accessed on 2018 May 21].

3. Treyster Z, Gitterman B. Second hand smoke exposure in children: Environmental factors, physiological effects, and interventions within pediatrics. Rev Environ Health 2011;26:187-95

4. Jyothirmayi B, Kaviarasi S, William E. Study of glycated hemoglobin in chronic cigarette smokers. Int J Pharm Clin Res 2013;5:4-6.

5. Hireche A, Chaoui-kherouatou N, Ribouh A, Abadi N, Shi M, Satta D. Polymorphic deletions of glutathione s-transferases $\mathrm{m} 1$, $\mathrm{t} 1$ and bladder cancer risk in Algerian population. Asian J Pharm Clin Res 2018;11:458.

6. Center for Disease Control and Prevention. Fact Sheet 2010 Surgeon General's Report How Tobacco Smoke Causes Disease: The Biology and Behavioral Basis for Smoking-Attributable Disease. Available from: https://www.cdc.gov/tobacco/data_statistics/sgr/2010/index.htm. [Last accessed on 2017 May 31].

7. Doss DS, Anandhalakshmi S, Rekha K, Antony KA. Effect of smoking on heart rate variability in normal healthy volunteers. Asian J Pharm Clin Res 2016;9:230-4.

8. Shivasekar M, Vinodhini VM, Kumar YR. Study of serum ferritin in smokers. Asian J Pharm Clin Res 2018;11:11-12.

9. Sajid N, Bangash AL, Hashim N, Ismail NE. Smoking status affecting survival of adenocarcinoma lung cancer patients in Kuala Lumpur, Malaysia. Asian J Pharm Clin Res 2017;10:63-4.

10. Global Initiative for Asthma. Pocket Guide for Asthma Management and Prevention. Glob Initiat Asthma; 2016. p. 28

11. Riset Kesehatan Dasar. Badan Penelitian dan Pengembangan Kesehatan. Balitbangkes. Riset Kesehatan Dasar; 2013.
12. Bisgaard H, Bønnelykke K. Long-term studies of the natural history of asthma in childhood. J Allergy Clin Immunol 2010;126:187-97.

13. Rina A, Eff Y. Incidence of hypertension in asthma patients who treated with beta-2 agonists bronchodilators. Int J Pharm Pharm Sci 2017:9:2-5.

14. Willers S, Gerhardsson L, Lundh T. Environmental tobacco smoke(ETS) exposure in children with asthma-relation between lead and cadmium, and cotinine concentrations in urine. Respir Med 2005;99:1521-7.

15. Hoh E, Hunt RN, Quintana PJ, Zakarian JM, Chatfield DA, Wittry BC, et al. Environmental tobacco smoke as a source of polycyclic aromatic hydrocarbons in settled household dust. Environ Sci Technol 2012;46:4174-83.

16. Perfetti T. The chemical components of tobacco and tobacco smoke. Chromatographia 2010;71:977.

17. Montefort S, Ellul P, Montefort M, Caruana S, Grech V, Agius Muscat $\mathrm{H}$, et al. The effect of cigarette smoking on allergic conditions in maltese children (ISAAC). Pediatr Allergy Immunol 2012;23:472-8.

18. Holt PG. Immune and inflammatory function in cigarette smokers. Thorax 1987;42:241-9.

19. Sopori ML, Kozak W. Immunomodulatory effects of cigarette smoke. J Neuroimmunol 1998;83:148-56.

20. Koenig JQ, Mar TF, Allen RW, Jansen K, Lumley T, Sullivan JH, et al. Pulmonary effects of indoor- and outdoor-generated particles in children with asthma. Environ Health Perspect 2005;113:499-503.

21. Gullstén H. Significance of Polymorphisms in CYP2A6 Gene. Oulu: Department of Pharmacology and Toxicology, University of Oulu; 2000.

22. Rao Y, Hoffmann E, Zia M, Bodin L, Zeman M, Sellers EM, et al. Duplications and defects in the CYP2A6 gene: Identification, genotyping, and in vivo effects on smoking. Mol Pharmacol 2000;58:747-55

23. Hukkanen J, Jacob P $3^{\text {rd }}$, Benowitz NL. Metabolism and disposition kinetics of nicotine. Pharmacol Rev 2005;57:79-115.

24. Davies GE, Soundy TJ. The genetics of smoking and nicotine addiction. S D Med 2009;Spec No:43-9.

25. Mao J, Liu J, Pang X, Li M, Song J, Han C, et al. Nicotine induces the expression of C-reactive protein via MAPK-dependent signal pathway in U937 macrophages. Mol Cells 2012;34:457-61.

26. Nagasaki T, Matsumoto H, Nakaji H, Niimi A, Ito I, Oguma T, et al. Smoking attenuates the age-related decrease in igE levels and maintains eosinophilic inflammation. Clin Exp Allergy 2013;43:608-15.

27. Mshimesh BA. Effects of etoricoxib, zileuton, and their combination on urinary PGE-M and LTE4 levels in iraqi smokers: A comparative study. Int J Pharm Pharm Sci 2016;8:182-7.

28. Seccareccia F, Zuccaro P, Pacifici R, Meli P, Pannozzo F, Freeman KM, et al. Serum cotinine as a marker of environmental tobacco smoke exposure in epidemiological studies: The experience of the MATISS project. Eur J Epidemiol 2003;18:487-92.

29. Matsumoto A, Ino T, Ohta M, Otani T, Hanada S, Sakuraoka A, et al. Enzyme-linked immunosorbent assay of nicotine metabolites. Environ Health Prev Med 2010;15:211-6.

30. Kalkbrenner AE, Hornung RW, Bernert JT, Hammond SK, Braun JM, Lanphear BP, et al. Determinants of serum cotinine and hair cotinine as biomarkers of childhood secondhand smoke exposure. J Expo Sci Environ Epidemiol 2010;20:615-24.

31. Avila-Tang E, Al-Delaimy WK, Ashley DL, Bernert JT, Kim S, Samet JM. Assessing secondhand smoke using biological markers. Tob Control 2013;22:164-71.

32. Karadag B, Karakoc F, Ceran O, Ersu R, Inan S, Dagli E. Does passive smoke exposure trigger acute asthma attack in children? Allergol Immunopathol (Madr) 2003;31:318-23

33. Jingyi Xu, Smiley-Jewell S, Claude J, Pinkerton KE. Effects of environmental tobacco smoke during early life stages. Lung $2015 ; 12: 385-97$

34. Sutaryono P, Hartono H, Probandari NA, Setyono P, Budiastuti S, Masykuri M. Association between Exposure to Environmental Tobacco Smoke and the Risk of Uncontrolled Asthma in Children. In: International Conference on Public Health. Indonesia: Masters Program in Public Health, Graduate School, Universitas Sebelas Maret.

35. Chilmonczyk BA, Luis M, Salmun R, Keith N, Megathlin L, Louis M, et al. Association between exposure to environmental tobacco smoke and exacerbation of asthma in children. N Engl J Med 1993;328:1665-9.

36. Gergen PJ, Fowler JA, Maurer KR, Davis WW, Overpeck MD. The burden of environmental tobacco smoke exposure on the respiratory health of children 2 months through 5 years of age in the United States: Third national health and nutrition examination survey, 1988 to 1994. Pediatrics 1998;101:E8.

37. Gilliland FD, Islam T, Berhane $\mathrm{K}$, Gauderman WJ, McConnell R, Avol E, et al. Regular smoking and asthma incidence in adolescents. 
Am J Respir Crit Care Med 2006;174:1094-100.

38. Yang GH, Ma JM, Liu N, Zhou LN. Smoking and passive smoking in chinese, 2002. Zhonghua Liu Xing Bing Xue Za Zhi 2005;26:77-83.

39. Hayatbakhsh MR, Sadasivam S, Mamun AA, Najman JM, Williams GM, O'Callaghan MJ, et al. Maternal smoking during and after pregnancy and lung function in early adulthood: A prospective study. Thorax 2009;64:810-4.

40. Benowitz NL. Biomarkers of environmental tobacco smoke exposure. Environ Health Perspect 1999;107 Suppl 2:349-55.

41. Plaza V, Álvarez F, Calle M, Casanova C, Cosío BG Vina L. GEMA (Spanish guideline on the management of asthma). Arch Bronconeumol 2009;45 Supl 7:2-35.
42. Jindal SK, Gupta D. The relationship between tobacco smoke and amp; bronchial asthma. Indian J Med Res 2004;120:443-53.

43. Di Stefano A, Capelli A, Lusuardi M, Caramori G, Balbo P, Ioli F, et al. Decreased $\mathrm{T}$ lymphocyte infiltration in bronchial biopsies of subjects with severe chronic obstructive pulmonary disease. Clin Exp Allergy 2001;31:893-902.

44. Prakruthi GM, Bharathi DR, Yogananda R. A case control study on determinants of childhood asthma in school children of Chitradurga city. Int J Curr Pharm Res 2018;10:11-5.

45. Mahmudah RA, Adnyana IK, Kurnia N. Anti-asthma activity of tamarind pulp extract (Tamarindus indica L.). Int J Curr Pharm Res 2017;9:3-6. 